\title{
GAMBARAN PERILAKU HIDUP BERSIH DAN SEHAT PADA PETUGAS KEBERSIHAN DI ERA PANDEMI COVID-19
}

\author{
Putu Nita Cahyawati ${ }^{*}$, Ni Kadek Elmy Saniathi ${ }^{2}$ \\ ${ }^{1}$ Departemen Farmakologi dan Farmasi, Fakultas Kedokteran dan Ilmu Kesehatan, Universitas \\ Warmadewa \\ ${ }^{2}$ Departemen Biokimia, Fakultas Kedokteran dan Ilmu Kesehatan, Universitas Warmadewa \\ *putunitacahyawati@gmail.com
}

\begin{abstract}
Abstrak
Petugas kebersihan merupakan salah satu tenaga yang sangat penting dalam pelayanan di klinik, puskesmas, maupun di rumah sakit. Hal ini dikarenakan tempat tersebut merupakan lokasi berkumpulnya orang sakit maupun sehat. Kondisi ini menyebabkan tingginya risiko penularan penyakit infeksi di tempat ini, termasuk terjadinya pencemaran lingkungan. Kegiatan ini bertujuan untuk mengetahui gambaran perilaku hidup bersih dan sehat khususnya bagi para petugas kebersihan di tempat pelayanan kesehatan. Instrumen yang digunakan pada kegiatan ini adalah kusioner. Berdasarkan hasil pengisian kuesioner, temukan bahwa seluruh responden telah menggunakan masker saat melakukan aktivitas di luar rumah. Walaupun demikian, belum seluruh responden dapat mempertahankan untuk tidak membukan masker saat bekerja. Perilaku hidup dan sehat di lingkungan keluarga juga belum diterapkan sesuai protokol yang dianjurkan dan belum diterapkan secara konsisten. Dengan demikian, dapat dismpulkan bahwa penerapkan perilaku hidup bersih dan sehat baik di keluarga maupun di tempat kerja belum dilakukan secara konsisten, sehingga, dapat meningkatkan risiko penularan COVID-19.
\end{abstract}

Kata kunci: COVID-19, perilaku hidup bersih dan sehat, petugas kebersihan

\section{Pedahuluan}

Petugas kebersihan merupakan salah satu tenaga yang sangat penting dalam pelayanan di klinik, puskesmas, maupun di rumah sakit. Hal ini dikarenakan tempat tersebut merupakan lokasi berkumpulnya orang sakit maupun sehat. Kondisi ini menyebabkan tingginya risiko penularan penyakit infeksi di tempat ini, termasuk terjadinya pencemaran lingkungan. Oleh karenanya, peran petugas kebersihan menjadi sangat penting. Terdapat tiga konsep yang harus dimiliki oleh petugasa cleaning service yaitu kebersihan, kerapian, dan ketelitian. ${ }^{1}$

Salah satu hasil penelitian melaporkan petugas kebersihan memiliki risiko terpapar kuman, bakteri dan virus serta terpapar obat kemoterapi, dengan tingkat risiko termasuk dalam high risk dengan persentase sebesar $36,6 \%$. Petugas kebersihan juga memiliki risiko 
tertusuk jarum suntik atau tergores benda tajam, terpeleset atau jatuh karena lantai licin, gangguan muskuloskeletal, terjatuh dari tangga, dan tersengat listrik merupakan risiko dengan tingkatan moderate risk dengan persentase sebesar $45,1 \%$. Risiko alergi atau iritasi terhadap penggunaan bahan kimia merupakan risiko dengan tingkatan low risk dengan persentase sebesar 18,3\%. Oleh karenanya, penting bagi petugas kebersihan agar selalu menggunakan alat pelindung diri yang baik dan benar saat melakukan pekerjaan, menggunakan jenis alat pelindung diri (APD) yang sesuai dengan pekerjaan yang dilakukan. ${ }^{2}$ Penggunaan APD tidak hanya diperuntukkan bagi petugas kebersihan. Di era pandemi ini masyarakat juga diwajibkan menggunakan APD khususnya masker guna melindungi diri dari penularan virus COVID-19. Akan tetapi, perilaku penggunaan masker nampaknya masih belum dilakukan dengan baik bagi sebagian masyarakat. ${ }^{3}$ Kondisi ini dapat disebabkan karena banyak faktor, salah satunya adalah karena rendahnya pengetahuan masyarakat terkait COVID-19 tersebut. ${ }^{4}$ Perilaku hidup bersih dan sehat, salah satunya seperti mencuci tangan dilaporkan berhubungan dengan penurunan risiko penyakit infeksi (baik infeksi bakteri maupun virus). Oleh karenannya, penting untuk tetap menerapkan perilaku hidup bersih dan sehat (PHBS) bagi setiap orang khususnya bagi para petugas kebersihan. ${ }^{5}$

\section{Metode}

Studi ini merupakan studi awal untuk mengetahui gambaran PBHS pada petugas kebersihan di beberapa klinik di Denpasar, Bali. Gambaran PHBS dinilai dengan pengisian kuesioner. Kuesioner dibagi ke dalam 2 bagian yaitu kuesioner tentang PHBS di lingkungan kerja dan PBHS di rumah/keluarga. Perilaku dikategorikan dalam menjadi "tidak pernah", "kadang-kadang", "sering", dan "selalu".

\section{Hasil dan Diskusi}

Petugas kebersihan yang terlibat dalam kegiatan ini sejumlah 5 orang. Jumlah ini sesuai dengan target awal yang ditetapkan. Dengan demikian, persentase kehadiran sebesar 100\%. Karakteristik responden yang terlibat seperti tampak pada Tabel 1. Responden berada pada rentang usia 26 tahun hingga 46 tahun. Didominiasi oleh perempuan yaitu sebanyak 4 orang (80\%) dan 1 laki-laki (20\%). Pendidikan terakhir mitra yaitu SMP sebanyak 2 orang, SMA sebanyak 2 orang, dan SMK sebanyak 1 orang. Mayoritas mitra beragama Hindu (80\%) dan siasanya (20\%) beragama Islam. Masa kerja mitra bervariasi yaitu antara 2-5 tahun. Walaupun demikian, seluruh reponden memiliki jadwal kerja yang sama yaitu 6 kali per minggu. Berdasarkan hasil diskusi diketahui bahwa 1 dari 5 responden pernah terdiagnosis COVID-19. Selama informasi tentang COVID-19 diperoleh dari televisi, media sosial, atau orang-orang sekitar. 
Tabel 1. Karakteristik Responden

\begin{tabular}{|c|c|c|c|c|c|}
\hline Karakteristik Responden & $\mathrm{R} 1$ & $\mathrm{R} 2$ & R3 & R4 & R5 \\
\hline Usia (tahun) & 29 & 25 & 46 & 34 & 26 \\
\hline Jenis kelamin & $\mathrm{P}$ & $\mathrm{L}$ & $\mathrm{P}$ & $\mathrm{P}$ & $\mathrm{P}$ \\
\hline Pendidikan & SMP & SMK & SMP & SMA & SMA \\
\hline Agama & Hindu & Hindu & Hindu & Islam & Hindu \\
\hline Status pernikahan & Menikah & Menikah & Menikah & Menikah & Menikah \\
\hline Masa kerja (tahun) & 3 & 3 & 5 & 5 & 2 \\
\hline $\begin{array}{l}\text { Jadwal kerja } \\
\text { minggu (kali) }\end{array}$ & 6 & 6 & 6 & 6 & 6 \\
\hline
\end{tabular}

Keterangan: R (responden), P (perempuan), L (laki-laki)

Berdasarkan hasil pengisian kuesioner tampak bahwa perilaku menggunakan masker sebagai alat perlindungan penting di masa pandemi ini talah dilakukan oleh seluruh responden. Walaupun demikian, belum seluruh responden mampu untuk mempertahankan agar tidak melepaskan masker saat bekerja. Perilaku berjabat tangan dan kegiatan aktif melakukan kegiatan di luar juga masih dilakukan, sehingga kondisi-kondisi ini dapat menjadi faktor risiko penularan COVID-19. Tabel 2 dan 3 menggambarkan perilaku mengenai PHBS dalam kehidupan sehari-dari di rumah atau keluarga, maupun di tempat kerja.

Terkait perilaku PHBS di keluarga, perilaku mencuci tangan dengan sabun selalu dilakukan oleh mayoritas responden. Mayoritas responden juga belum secara konsisten untuk memberishkan permukaan benda dengan cairan desinfektan serta membuka ventilasi rumah setiap harinya. Perilaku menerapkan etika batuk dan bersin yang benar, serta perilaku mencuci tangan setelah memegang uang juga belum diterapkan dengan ketat, sehingga dapat menjadi faktor risiko penularan COVID-19. Seperti telah diketahui bahwa COVID-19 merupakan jenis penyakit yang dapat tertular dari manusia ke manusia. Salah satu upaya yang dapat dilakukan untuk mencegah transmisi penyakit ini adalah dengan penerapan PHBS seperti mencuci tangan dengan sabun, menggunakan air bersih, dan mengonsumsi makanan bergizi. ${ }^{6}$ Konsistensi dalan penerapan PHBS ini dapat dipengaruhi oleh banyak faktor. Suatu studi melaporkan bahwa terdapat empat faktor yang dapat mempengaruhi pengetahuan dan perilaku masyarakat dalam penerapan PHBS pada saat pandemi COVID-19. Faktor tersebut antara lain faktor penyakit bawaan, pengetahuan, tindakan, dan sikap. ${ }^{7}$ 
Tabel 2. Gambaran perilaku PHBS di keluarga

\begin{tabular}{|c|c|c|c|c|}
\hline \multirow[b]{2}{*}{ Jenis perilaku } & \multicolumn{4}{|c|}{ Ketegori perilaku } \\
\hline & $\begin{array}{l}\text { Tidak } \\
\text { pernah }\end{array}$ & $\begin{array}{l}\text { Kadang- } \\
\text { kadang }\end{array}$ & Sering & Selalu \\
\hline $\begin{array}{l}\text { Perilaku mencuci tangan menggunakan sabun setelah keluar } \\
\text { rumah }\end{array}$ & 0 & 1 & 2 & 2 \\
\hline Perilaku mencuci tangan menggunakan sabun sebelum makan & 0 & 0 & 1 & 4 \\
\hline Perilaku membersihkan rumah setiap hari & 0 & 1 & 0 & 4 \\
\hline Perilaku membuka jendela dan ventilasi di rumah & 1 & 3 & 0 & 1 \\
\hline $\begin{array}{l}\text { Perilaku membersihkan permukaan benda yang ada di rumah } \\
\text { dengan cairan pembersih setiap hari }\end{array}$ & 0 & 2 & 1 & 2 \\
\hline Perilaku menyediakan makanan sehat & 0 & 2 & 2 & 1 \\
\hline Perilaku anggota keluarga yang tetap merokok & 1 & 2 & 2 & 0 \\
\hline Perilaku berolahraga minimal 30 menit sehari & 1 & 3 & 1 & 0 \\
\hline Perilaku menyiapkan makanan cepat saji untuk keluarga & 0 & 3 & 1 & 1 \\
\hline Perilaku mencuci sayuran dan buah sebelum dikonsumsi & 0 & 0 & 0 & 5 \\
\hline Perilaku mencuci tangan setelah memegang uang & 0 & 1 & 3 & 1 \\
\hline Perilaku membiasakan seluruh keluarga untuk hidup sehat & 0 & 0 & 2 & 3 \\
\hline Perilaku mengkonsumsi minimal 2 liter air putih dalam sehari & 0 & 0 & 4 & 1 \\
\hline Perilaku masih aktif melakukan perjalanan ke luar kota & 3 & 2 & 0 & 0 \\
\hline
\end{tabular}

Tabel 3. Gambaran Perilaku PHBS di tempat kerja

\begin{tabular}{|c|c|c|c|c|}
\hline \multirow{2}{*}{ Jenis perilaku } & \multicolumn{4}{|c|}{ Ketegori perilaku } \\
\hline & $\begin{array}{l}\text { Tidak } \\
\text { pernah }\end{array}$ & $\begin{array}{l}\text { Kadang- } \\
\text { kadang }\end{array}$ & Sering & Selalu \\
\hline Perilaku menggunakan masker saat keluar rumah/bekerja & 0 & 0 & 0 & 5 \\
\hline Perilaku melepaskan masker saat bekerja & 4 & 1 & 0 & 0 \\
\hline $\begin{array}{l}\text { Perilaku menggunakan alat pelindung diri yang memadai saat } \\
\text { bekerja }\end{array}$ & 1 & 1 & 0 & 3 \\
\hline Perilaku anda menggunakan pakaian khusus saat bekerja & 2 & 1 & 0 & 2 \\
\hline $\begin{array}{l}\text { Perilaku mencuci tangan dengan sabun dan air mengalir setelah } \\
\text { bekerja }\end{array}$ & 1 & 0 & 1 & 3 \\
\hline Perilaku menjaga jarak aman 2 meter dengan orang sekitar & 0 & 1 & 0 & 4 \\
\hline Perilaku menggunakan cairan desinfektan selama bekerja & 0 & 0 & 2 & 3 \\
\hline Perilaku menerapkan etika batuk dan bersin yang benar & 0 & 1 & 3 & 1 \\
\hline Perilaku langsung mandi dan keramas sepulang dari tempat kerja & 0 & 1 & 1 & 3 \\
\hline Perilaku berjabat tangan dengan orang lain & 1 & 4 & 0 & 0 \\
\hline Perilaku aktif melakukan kegiatan di luar rumah & 0 & 2 & 3 & 0 \\
\hline
\end{tabular}

\section{Kesimpulan}

Petugas kebersihan belum menerapkan perilaku hidup bersih dan sehat baik di keluarga maupun di tempat kerja secara konsisten. Keadaan ini tentunya dapat meningkatkan risiko penularan COVID-19 di era pandemi ini.

\section{Daftar Pustaka}

1. Anonim. 2020. Petugas Kebersihan Sebagai Satu Tenaga Penting di Rumah Sakit. Available at: https://rsud.ntbprov.go.id/2020/08/11/ petugas-kebersihan-sebagai-satutenaga-penting-di-rumah-sakit/ 
2. Yuantari, MGC. dan Nadia, H. Analisis Risiko Keselamatan dan Kesehatan Kerja Pada Petugas Kebersihan di Rumah Sakit. Faletehan Health Journal, 2018. 5 (3): 107-116

3. Cahyawati, PN., Lestarini, A., Saniathi, NKE. Konsultasi Online dan Pendampingan Masyarakat Desa Dalung Dalam Rangka Pencegahan Penularan COVID-19. Buletin Udayana Mengabdi, 2021. 20(2):123128

4. Permatananda, P., Aryastuti, A., Cahyawati, P., \& Udiyani, D. Online Based Community Empowerment in Bukian Village, Bali as an Effort to Prevent Covid19 Transmission. Jurnal Peduli Masyarakat, 2020. 2(4), 187196.

5. Alvadri, Z, Hubungan Pelaksanaan Tindakan Cuci Tangan Perawat dengan Kejadian Infeksi Rumah Sakit di Rumah Sakit Sumber Waras Grogol. Available at: https://digilib.esaunggul.ac.id/public/ UEU-Undergraduate7874JURNAL\%20PENELITIAN.pdf

6. Alia, E.C. Perilaku Hidup Bersih Dan Sehat (PHBS) Dalam Pencegahan Covid-19. Jurnal Medika Malahayati, 2020. 4(4):298-304

7. Kasrudin, I., Agus, F., Kurniawan, W., et al. Perilaku Hidup Bersih Sehat (PHBS) Dalam Mendukung Gaya Hidup Sehat Masyarakat Kota Kendari Pada Masa Pandemic COVID-19.
Jurnal Keperawatan, 2021, 4(3): 1927. 